УДК 784.4 .088

DOI 10.34064/khnum2-2107

\title{
Чжан Лін
}

ORCID $000000023833129 \mathrm{X}$

Харківський національний університет мистецтв імені І. П. Котляревського, 61003, майдан Конституиії 11/13, м. Харків, Україна

\section{Жанр обробки народної пісні: шляхи взаємодії традиційного та професійного музичного мистецтва}

АНОТАЦІЯ Ч Чжан Лін. Жанр обробки народної пісні: шля-
хи взасмодії традиційного та професійного музичного мистецтва. - Представлена стаття присвячена жанру обробки народної пісні в аспекті специфіки шляхів взаємодії традиційного та професійного музичного мистецтва. Під традиційним ми розуміємо народну музичну творчість усної природи, «колективного» авторства, а під професійним - академічне музичне мистецтво композиторської, авторської природи (обидва види музичної творчості в європейській культурі). Кожен з цих видів творчості має у першоджерелі свою специфіку - жанрову, стильову, образну, мовну, виконавську, і способи взаємодії традиційного та професійного на цих основних рівнях впливають як на сам жанр обробки народної пісні, так і на його сценічну презентацію. 3 точки зору сучасного музикознавства, яке включає в систему жанру і його виконавську специфіку, обробка народної пісні постає як результат синтезу композиторської та виконавської інтерпретацій, що багато в чому обумовлює виконавську специфіку творів, написаних в даному жанрі, в різних історичних і сценічних умовах, а також породжує нові перспективи його вивчення. — Ключові слова: жанр, обробка народної nicнi, традииійне музичне мистецтво, професійне музичне мистецтво, музичне виконавство.

АННОТАЦИЯ — Чжан Лин. Жанр обработки народной песни: пути взаимодействия традиционного и профессионального музыкального искусства. - Представленная статья посвящена жанру обработки 
народной песни в аспекте специфики путей взаимодействия традиционного и профессионального музыкального искусства. Под традиционным мы понимаем народное музыкальное творчество устной природы, «коллективного» авторства, а под профессиональным - академическое музыкальное искусство композиторской, авторской природы (оба вида музыкального творчества в европейской культуре). Каждый из этих видов творчества имеет в первоисточнике свою специфику - жанровую, стилевую, образную, языковую, исполнительскую, и способы взаимодействия традиционного и профессионального на этих основных уровнях влияют как на облик самого жанра обработки народной песни, так и на его сценическую презентацию. С точки зрения современного музыковедения, которое включает в систему жанра и его исполнительскую специфику, обработка народной песни предстаёт как результат синтеза композиторской и исполнительской интерпретаций, что во многом обуславливает исполнительскую специфику произведений, написанных в данном жанре, в разных исторических и сценических условиях, а также порождает новые перспективы его изучения. - Ключевые слова: жанр, обработка народной песни, традиционное музыкальное искусство, профессиональное музыкальное искусство, музыкальное исполнительство.

\section{ABSTPACT - Zhang Ling. The genre of folk song settings: the ways of interaction of traditional and professional musical art.}

- Logical reason for research. The contemporary music science is becoming an increasingly multifaceted research field. This is connected with the evolution of musical art in general (its language, genre system, stylistic diversity), and its interaction with other manifestations of human creativity, and with new aspects of studying the achievements of world and national culture. One of the topical perspectives of scientific attention over the past decades has been the attention of musicologists to musical practice, in particular, to musical performance in all its multi-vector manifestations - in its genesis, historical retrospective and general cultural, civilizational context, in its syncretic unity with the composing creativity, in its palette of forms and genres of musical practice, in the traditions and perspectives in musical science and the existence in modern cultural conditions.

Innovation. The presented article is devoted to the genre of folk song settings in the aspect of the specifics of the ways of interaction between traditional and 
professional musical art. By traditional we mean folk musical creativity of an oral nature, of "collective" authorship, and by professional - academic musical art of a composing, author's nature (both types of musical creativity in the European culture). Each of these types of creativity has its own specificity in the primary source - the genre, style, figurative, linguistic, performing one, and the ways of interaction at these basic levels affect both the genre of folk song settings and its stage presentation. In the theoretical aspect, the genre of folk song settings is the result of a synthesis of composing and performing interpretation, and in the performing aspect, in fact, an interpretation of interpretation, which determines new perspectives of its study.

Objectives. The purpose of this research is to characterize the ways of interaction between traditional and professional musical art on the example of the genre of setting a folk song in genre-style and performing aspects.

Methods. The main methods of the presented research are the genre one and the performing one. The genre method is necessary both for characterizing the basic constants of the folk song settings genre, especially those related to the synthesis of traditional and professional musical art, and for identifying the specifics of this genre in the performing aspect. The performing method makes it possible to identify those features of the genre of folk song settings that are associated with its performing specificity as one of the most important areas of manifestation of the above-mentioned synthesis.

Results and Discussion. One of the burning thematic areas of modern musicology is vocal music, its genre, style and performing specifics. It is related to the issues of the interaction of words and music, the methods of expressiveness, the stage presentation and the interpretation of vocal compositions, in particular, taking into account the specifics of style and genre through the prism of modern concert practice. This also applies to the genre of folk song settings, which is representing the traditions of both folk and professional music, with which this research is connected.

The synthetic genre nature of folk song settings, which has been preserved in the process of the historical development of the genre and is based on the interpretation of the composing and performing character as the main genre indicator, increases the degree of relevance of the scientific research of this genre phenomenon both in theoretical and practical aspects, with a projection on the needs of the composing and performing art in the modern cultural conditions. 
The problem of an adequate reflection of the intonation and figurative content of the original folk source in the genre of folk song settings has always been the focus of attention of both folklorists, who collected samples of folk song creativity, and composers - authors of the settings of folk songs, and researchers of musical art.

The ways of interaction between traditional and professional musical creativity pass through the main levels of a musical composition, which are always interconnected and represent a complex living organism, where changes in one segment can affect all the others. We are talking about genre-style, figurative, linguistic (intonation) and performing aspects.

The latter should be emphasized separately, since in the field of the traditional, folk musical creativity, the performing presentation is a syncretic component, and this applies to any type of folk art. In professional musical art, where authorship (historically, first the composing one, and then the performing one) became a separate component, the performing aspect acquires a special meaning and its own specific tasks, and this way of interaction between traditional and professional musical art is the field where there happens the actualization of one or another quality (from one or another component of the above-mentioned synthesis) of the performed composition in the genre of folk song settings.

Conclusions. The genre of folk song settings by its origin is associated with several levels of specificity - the figurative and artistic, linguistic, genre, style, and performing one. All these levels in this genre represent two types of musical art, the interaction of which allowed the genre of folk song settings to appear the traditional (folk, collective) musical creativity and the professional (author's) musical art (in particular, that of the European tradition). The peculiarities of the interaction of these two musical worlds in the genre of folk song settings represent different ways, and they are all connected with each other, which gives rise to new perspectives - the composing, performing, and research ones.

The possibilities for the further research in the direction which is fixed in the topic of the presented article are associated with the characteristic of the synthetic genre nature of the settings of a folk song. Combining the features of traditional musical art (as the music of the oral tradition) and the patterns of professional musical art (as the author's musical creativity with a fixed recording), the settings of a folk song offers the composer, the performer, the listener, and the musicologist a number of special tasks that can be solved in the special conditions of accounting 
the above-mentioned specificity of the genre of folk song settings, which is the composing and performing interpretation of the original folklore source. - Key words: genre, folk song settings, traditional musical art, professional musical art, musical performance.

Постановка проблеми. Сучасна музична наука стає все більш багатоаспектним дослідницьким полем. Це пов'язано і $з$ еволюцією музичного мистецтва в цілому (його мови, жанрової системи, стильового розмаїття), і його взаємодією з іншими проявами творчості людини, і з новими аспектами вивчення досягнень світової і національної культури. Одним 3 актуальних ракурсів наукової уваги протягом останніх десятиліть $є$ інтерес музикознавців до музичної практики, зокрема, до музичного виконавства у всій багатовекторності його проявів - у його генезі, історичній ретроспективі та загальнокультурному, цивілізаційному контексті, в його синкретичній єдності з композиторською творчістю, в його розмаїтій палітрі форм і жанрів, традицій і перспектив у музичній науці та побутуванні в сучасних культурних умовах.

Представлене дослідження присвячене жанру обробки народної пісні в аспекті специфіки шляхів взаємодії традиційного та професійного музичного мистецтва. Під традиційним ми розуміємо народну музичну творчість усної природи, «колективного» авторства, а під професійним - академічне музичне мистецтво композиторської, авторської, природи (обидва види музичної творчості в європейській традиції). Кожен з цих видів творчості має в першоджерелі свою специфіку - жанрову, стильову, образну, мовну, виконавську, і шляхи взаємодії на цих основних рівнях впливають як на жанр обробки народної пісні, так і на його сценічну презентацію. 3 точки зору сучасного музикознавства, яке включає в систему жанру його виконавську специфіку, обробка народної пісні є результатом синтезу композиторської та виконавської інтерпретації, що багато в чому обумовлює виконавську специфіку творів, написаних в даному жанрі, в різних історичних і сценічних умовах, а також породжує нові перспективи його вивчення. 
Огляд літератури. Особливості взаємодії традиційного та професійного музичного мистецтва, в результаті якої народжується окремий музичний жанр, привертають увагу музикантів та музикознавців досить давно, власне, практично від початку цілеспрямованого збирання зразків музичного фольклору та його використання (зокрема, різних форм цитування) в професійній музичній творчості. Специфіка збереження образності, а також інтонаційних рис (у тому числі в аспекті національно-культурної специфіки) в жанрі обробки народної пісні регулярно ставала предметом обговорення вчених. Це питання в певний час набувало особливо гострої актуальності - наприклад, у дебатах вчених, композиторів, виконавців, музичних соціологів та культурологів, приблизно з другої половини XIX ст., час від часу підвищувався градус дискусійності цієї проблематики. Власне, у XX ст. тенденція до виявлення глибинної природи народної пісні i, ширше, специфіки традиційної (народної) музичної культури втілилася в таких явищах, як «неофольклоризм» (перша половина XX ст.) і «нова фольклорна хвиля» (друга половина XX ст.). Відповідно, в музичній науці з'явився ряд досліджень 3 цієї проблематики. В першу чергу, треба згадати грунтовні праці «Фольклор и композитор. Теоретические этюды о русской советской музыке» (Земцовський, 1978) та «Композитор и фольклор. Из опыта мастеров XIX-XX веков» (Головинський, 1981), в яких були систематизовані основні теоретичні та практичні питання збереження традиційної музики в XX ст., у тому числі, в аспекті взаємодії з професійним музичним мистецтвом. На початку нинішнього століття з'явилися наукові праці, в яких досліджуються різноманітні теоретично-практичні питання життя фольклору в сьогоденні. Так, можна згадати наукову розвідку про сучасні форми побутування фольклору (Осадча, 2000); про національну семантику в музичному виконавстві, а саме, про знаки традиційної музичної культури (Чайка, 2007); про особливості виконавської роботи співаків, що мають справу з традиційною музикою (Гапон, 2010). Однак перспектива досліджень у окресленому напрямку ще досить багата, вона містить досить незвіданого, частиною якого можна вважати жанр обробки народної пісні, де відбувається складна взаємодія традиційної (народної, автентичної) та академічної (як композиторської, так і виконавської) музичної творчості. 
Мета представленого дослідження - охарактеризувати шляхи взаємодії традиційного та професійного музичного мистецтва на прикладі жанру обробки народної пісні в жанрово-стильовому і виконавському аспектах.

Основні методи представленого дослідження - жанровий і виконавський. Жанровий метод необхідний як для характеристики основних констант жанру обробки народної пісні, особливо, пов'язаних iз синтезом традиційного та професійного музичного мистецтва, так і для виявлення специфіки даного жанру в виконавському аспекті. Виконавський метод дозволяє виявити ті особливості жанру обробки народної пісні, які пов'язані з його виконавської специфікою як однією $з$ найважливіших сфер прояву вищезгаданого синтезу.

Виклад основного матеріалу. Одним 3 нагальних тематичних напрямків сучасного музикознавства $є$ вокальна музика, іiі жанрова, стильова і виконавська специфіка. 3 нею пов'язані питання взаємодії слова і музики, прийомів виразності, сценічної презентації та інтерпретації вокальних творів, зокрема, з урахуванням специфіки стилю і жанру крізь призму сучасної концертної практики. Це стосується і жанру обробки народної пісні, що представляє традиції як народної, так і професійної музики, чия взаємодія становить інтерес даного дослідження. Синтетична жанрова природа обробки народної пісні, яка збереглася в процесі історичного розвитку жанру і спирається на інтерпретаційний композиторсько-виконавський характер як на основний жанровий показник, підвищує ступінь актуальності наукового вивчення даного жанрового явища як в теоретичному, так і в практичному (а саме, виконавському) аспектах, з проекцією на потреби композиторської та виконавської творчості в сучасних культурних умовах. Проблема адекватного відображення інтонаційного і образного змісту народного першоджерела в жанрі обробки народної пісні завжди була в фокусі уваги і фольклористів, які збирали зразки народно-пісенної творчості, і композиторів - авторів обробок народних пісень, і дослідників музичного мистецтва.

Аналітична та композиторська робота 3 жанром обробки народної пісні, що пов'язана із зверненням до автентичного першоджерела, на практиці стикається з низкою складних питань. Так, порівняльний 
аспект народної пісні та ії обробки містить декілька окремих ракурсів. По-перше, це проблема автентичності - походження пісні й тотожності її запису, на який орієнтується композитор, їі усній версії; по-друге, це питання існування регіональних та національних варіантів першоджерела; по-третє - інтонаційних особливостей першоджерела, звуковисотних, динамічних тощо - які частково зафіксовані у нотах, однак, здебільшого, збережені в усній традиції. Наукова реакція на цю проблематику потребує окремого підходу та відповідного науково-методичного інструментарію, щоб отримати відповіді, які стануть новими точками опори для подальшого дослідження жанру обробки народної пісні як у теоретичному, так і в практичному плані.

Нагадаємо, що інтерпретаційна природа жанру обробки народної пісні, де композитор створює свою інтерпретаційну версію (за термінологією В. Москаленка, 2013) народного першоджерела, посилюється тим, що саме це джерело є багатоваріантним, тобто вже є носієм певного комплексу трактувань, і це створює додаткові поля для дослідження шляхів взаємодії фольклорного та професійного музичного мистецтва, в тому числі, щодо традицій та можливостей виконавства в сучасних культурних умовах, що позначені духом експериментування, формуванням нових комунікативних зв'язків, покликаних, з одного боку, відображати актуальні тенденції глобалізації, з іншого ж зберігати національно-культурну ідентичність, зокрема, і в мистецькому просторі, в сфері музичної творчості.

При цьому, одним з головних та надскладних завдань як для композитора - автора творів у жанрі обробки народної пісні, так і для їх виконавця, є збереження духу першоджерела, що міститься, насамперед, у його усній побутовій формі. Ця проблема пов'язана також 3 певними традиціями та особливостями професійної роботи спеціалістів з усною інформацією, загальні принципи якої фіксуються дослідниками сфери так званої «усної історії» (Thompson, 2000), і на яких базується відповідна методологія дослідження усних артефактів культури і мистецтва в області сучасної гуманітаристики, зокрема, й музикознавства.

Отже, шляхи взаємодії традиційної та професійної музичної творчості проходять по основним рівням музичного твору, котрі за- 
вжди пов’язані між собою і представляють складний живий організм, де зміни в одному сегменті можуть відбитися i, тим чи іншим чином, відбиваються, на всіх інших. Тобто, йдеться про його жанрово-стильовий, образний, мовний (інтонаційний) і виконавський аспекти.

Останній слід підкреслити окремо, бо у сфері традиційної, народної, музичної творчості виконавська презентація є синкретичною складовою, і це стосується будь-якого виду народної творчості. В професійному музичному мистецтві, де авторство (історично спочатку композиторське, а потім, і виконавське) стало окремою складовою, виконавський аспект набуває особливого змісту і має свої специфічні завдання. Цей шлях взаємодії традиційного та професійного музичного мистецтва є тим полем, де відбувається актуалізація певних якостей (з тієї чи іншої складової вищезгаданого синтезу) виконуваного твору в жанрі обробки народної пісні.

Висновки. Отже, жанр обробки народної пісні за своїм походженням пов'язаний з декількома рівнями специфіки - образно-художньої, мовної, жанрової, стильової, виконавської. Всі ці рівні в даному жанрі представляють два види музичного мистецтва, взаємодія яких і дозволила з'явитися жанру обробки народної пісні - традиційна (народна, колективна) музична творчість і професійне (авторське) музичне мистецтво (зокрема, європейської традиції). Особливості взаємодії цих двох музичних світів в жанрі обробки народної пісні відбуваються різними шляхами, і всі вони пов'язані один з одним, що постійно породжує цілий ряд нових перспектив - композиторських виконавських, дослідницьких.

Можливості подальших досліджень в напрямку, зафіксованому в темі представленої статті, пов'язані з характеристикою синтетичної жанрової природи обробки народної пісні. Об’ єднуючи в собі риси традиційного музичного мистецтва (як музики усної традиції) і закономірності професійного музичного мистецтва (як авторської музичної творчості з фіксованим записом), обробка народної пісні пропонує композитору, виконавцю, слухачеві, музикознавцю ряд спеціальних завдань, які можливо вирішити в особливих умовах врахування вищезгаданої специфіки жанру обробки народної пісні, який є композиторською та виконавською інтерпретацією фольклорного першоджерела. 


\section{ЛІТЕРАТУРА}

Гапон, Л. (2010). До проблеми виховання співака у вторинному фольклорному ансамблі. Вісник Львівського університету. Серія: Філологія, 43, 294-301.

Головинский, Г. Л. (1981). Композитор и фольклор. Из опыта мастеров XIX-XX веков. Очерки. Москва: Музыка, 280.

Земцовский, И. И. (1978). Фольклор и композитор. Теоретические этюды о русской советской музыке. Москва: Советский композитор, 172.

Москаленко, В. Г. (2013). Лекции по музыкальной интерпретации. Киев: Клякса, 271.

Осадча, В. М. (2000). Форми побутування фольклору в сучасному культурному середовищі. В сб. Міжнародна науково-практична конференція «Процес соиіалізаиії у контексті традииійної народної культури», сс. 38-41. Харків: Регіон-інформ.

Чайка, О. В. (2007). Національна характерність як семантична властивість виконавської інтерпретації. (Автореф. дис. ... канд. мистецтвознавства). Одеська державна музична академія ім. А. В. Нежданової. Одеса, 20.

Thompson, P. (2000). The Voice of the Past: Oral History. (Third edition). Oxford: Oxford University Press, 384.

\section{REFERENCES}

Chaika, O. V. (2007). Natsionalna kharakternist yak semantychna vlastyvist vykonavskoi interpretatsii [National characteristic as a semantic property of performing interpretation]. (Extended abstract of Candidate's thesis). Odessa National Nezhdanova Academy of Music. Odesa, 20 [in Ukrainian].

Golovinskiy, G. L. (1981). Kompozitor i folklor. Iz opyta masterov XIX-XX vekov. Ocherki. [Composer and folklore. From the experience of masters of the nineteenth and twentieth centuries. Essays]. Moscow: Muzyka, 280 [in Russian].

Hapon, L. (2010). Do problemy vykhovannia spivaka u vtorynnomu folklornomu ansambli [To the problem of the singer's education in the secondary folk ensemble]. Visnyk Lvivskoho universytetu. Seriia: Filolohiia [Bulletin of the University of Lviv. Series: Philology], 43, 294-301 [in Ukrainian].

Moskalenko, V. G. (2013). Lektsii po muzykalnoy interpretatsii [Lectures on musical interpretation]. Kiev: Klyaksa, 271 [in Russian]. 
Osadcha, V. M. (2000). Formy pobutuvannia folkloru v suchasnomu kulturnomu seredovyshchi [Forms of folklore in the modern cultural environment]. In Mizhnarodna naukovo-praktychna konferentsiia "Protses sotsializatsii u konteksti tradytsiinoi narodnoi kultury» [International scientific-practical conference "The process of socialization in the context of traditional folk culture”], pp. 38-41. Kharkiv: Rehion-inform [in Ukrainian].

Thompson, P. (2000). The Voice of the Past: Oral History. (Third edition). Oxford: Oxford University Press, 384.

Zemtsovskiy, I. I. (1978). Folklor i kompozitor. Teoreticheskie etyudy o russkoy sovetskoy muzyke [Folklore and composer. Theoretical sketches about Russian Soviet music]. Moscow: Sovetskiy kompozitor, 172 [in Russian].

Стаття надійшла до редакиії 11.02.2020 p. 